\title{
Deskripsi Status Gizi Anak Usia 3 Sampai 5 Tahun Pada Masa Covid 19
}

\author{
Aris Amirullah', Aris Try Andreas Putra ${ }^{2}$, dan Aris Armeth Daud Al Kahar ${ }^{3}$ \\ 1,2,3 Program Studi Tadris Biologi, Fakultas Tarbiyah dan Ilmu Keguruan, Institut Agama \\ Islam Negeri (IAIN) Kendari \\ e-mail : senacyza@gmail.com 1 aristryandreasputraaritonda@gmail.com² \\ arisarmeth@yahoo.com ${ }^{3}$
}

\begin{abstract}
ABSTRAK. Pola makan adalah cara seorang atau sekelompok orang yang memilih dan mengonsumsi makanan sebagai tanggapan terhadap pengaruh fisiologi, psikologi, budaya, dan sosial. Data di Sulawesi Utara untuk 2013 menunjukkan prevalensi status gizi BB/TB<-2SD tahun 2013 adalah 10\%. Kabupaten bolaang mongondow timur berdasarkan data jumlah penderita gizi buruk setiap tahun mengalami penurunan. Pada tahun 2017 kasus gizi buruk di Boltim berjumlah 2 orang. Pada tahun 2018 kasus bertambah tiga orang, sedangkan 2019 turun menjadi satu orang. Biasanya penyakit ini menyerang anak-anak berumur 0-59 bulan. ada upaya perhatian pemerintah terkait dengan penanganan gizi buruk hingga angka peningkatan gizi balita. Metode penelitian yang digunakan adalah metode survey termaksud dalam penelitian Deskriptif. Penelitian ini di laksanakan di PAUD/TK Ekasari Buyat I. Waktu penelitian bulan Februari Sampai Mei 2020. Populasi dan sampel dalam penelitian ini berjumlah 27 orang. Gambaran status Gizi anak gizi anak usia 3 sampai 5 tahun pada masa covid di PAUD/TK Ekasari Buyat I Kabupaten Bolaang Mongondow Timur adalah berada padabatas normal. Pengetahuan orang tua tentang gizi gizi anak usia 3 sampai 5 tahun pada masa covid di PAUD/TK Ekasari Buyat I Kabupaten Bolaang Mongondow Timur sebagian besar dalam keadaan baik.
\end{abstract}

Kata Kunci : Status Gizi, PAUD, Anak Usia Dini

ABSTRACT. Diet is an attempt to regulate the amount and type of food with an overview of information including maintaining health, nutritional status, preventing or helping cure diseases. Data in North Sulawesi for 2013 shows the prevalence of BW / TB nutritional status <-2SD in 2013 is 10\%. Bolaang mongondow Timur regency based on data on the number of sufferers of malnutrition every year has decreased. Since 2017 there have been two sufferers of malnutrition in Boltim. In 2018 there will be three people, while 2019 will become one person. Usually this disease attacks children aged 0-59 months. there is an effort of government attention related to the handling of malnutrition to the number of nutritional improvement in infants. The research method used is the intended survey method in descriptive research. This research was carried out in PAUD / TK Ekasari Buyat I. The time of the study was from February to May 2020. The population and sample in this study amounted to 27 people. The nutritional status of children of 3 to 5 years of age during the covidation at PAUD / TK Ekasari Buyat I of East Bolaang Mongondow Regency is within normal limits. Parents' knowledge of nutrition for children aged 3 to 5 years in the covid period at PAUD / TK Ekasari Buyat I of East Bolaang Mongondow Regency is mostly in good condition.

Keyword : Nutrition status, PAUD, early age 


\section{PENDAHULUAN}

Pola makan adalah suatu usaha dalam pengaturan jumlah dan jenis makanan dengan gambaran informasi meliputi mempertahankan kesehatan, status nutrisi, mencegah atau membantu kesembuhan penyakit serta Konsumsi zat gizi merupakan faktor yang berpengaruh langsung terhadap status gizi [1]. MDG's (Millenium Development Goals) merupakan salah satu tujuan dimana pada tahun 2015 setiap negara harus berupaya terus untuk menurunkan separuh jumlah penduduk miskin dan kelaparan yang juga terdampak pada kesehatan gizi anak-anak. Asupan makanan yang tidak sesuai dengan kebutuhan tubuh akan memicu masalah gizi yang nantinya berdampak pada rentannya tubuh terhadap penyakit dan hal ini sering terjadi di daerah atau negara berkembang. Di Indonesia pencapaian MDG's dengan indicator indikator paling menentukan untuk memberantas kemiskinan dan kelaparan adalah prevelensi gizi kurang dan gizi buruk. Adanya penurunan untuk prevalensi gizi kurang menurun secara signifikan di tahun 1989 dari 31\% menjadi 17,9\% di tahun 2010. Demikian pula prevalensi gizi buruk menurun dari 12,8\% (1995) menjadi 4,9\% (2010). Kecenderungan ini menunjukan target penurunan prevalensi gizi kurang dan gizi buruk menjadi $15 \%$ dan 3,5\% pada tahun 2015 ini dapat tercapai [2].

Usia dini dikenal juga dengan usia emas anak (the golden age). Mengacu pada UU RI N0. 20 Tahun 2003 tentang Sistem Pendidikan Nasional, yang dimaksud usia dini adalah anak yang berada pada rentang usia 0-6 tahun. Kebutuhan gizi sejak usia dini sangat penting, Asupan gizi yang seimbang akan membuat anak tumbuh sehat dan cerdas. Tidak terpenuhinya kebutuhan zat gizi tersebut, akan berdampak pada tumbuh kembang anak. Salah satunya, melambatnya pertumbuhan fisik, kurang cerdas dan kurang tangkas, daya tahan tubuh lebih rentan terhadap penyakit, serta lebih beresiko mengalami penyakit kronis seperti hipertensi, diabetes, jantung dan stroke [3]. Menurut Sumatri Anak usia dini yaitu anak yang sedang berada dalam pertumbuhan dan perkembangan yang pesat baik itu fisik atau psikis serta anak-anak yang berusia dibawah 6 tahun. Jadi mulai dari anak lahir hingga ia mencapai umur 6 tahun ia akan dikategorikan sebagai anak usia dini. Menurut Piaget dalam Sumantri anak usia dini berada pada masa lima tahun pertama yang disebut The Golden Age. Masa ini merupakan masa emas perkembangan anak. Menurut Agus Surono bahwa perkembangan otak anak yang sedang tumbuh melalui tiga tahapan, mulai dari otak primitif (action brain), otak limbik (feeling brain), dan akhirnya ke neocortex (atau disebut juga thought brain, otak pikir)[4]. Sujiono menyatakan bahwa pendidikan anak usia dini meliputi segala hal baik upaya maupun tindakan yang berikan oleh pendidik dan orang tua untuk memberikan stimulasi, bimbingan, perawatan dan pengasuhan pada anak usia dini sehingga tercipta suasana dan lingkungan yang memungkin anak dapat mengeksplorasi pengalaman, pengetahuan dan pemahaman terhadap pengalaman belajar yang telah diperoleh anak dari lingkungan, dengan cara mengamati, meniru, bereksperimen secara berulang-ulang dan melibatkan semua potensi dan kecerdasan anak[5]. Dari segi empiris banyak sekali penelitian yang menyimpulkan bahwa pendidikan anak usia dini sangat penting, karena pada waktu manusia dilahirkan, menurut Clark dalam Semiawan kelengkapan organisasi otaknya mencapai 100-200 
milyard sel otak yang siap dikembangkan dan diaktualisasikan untuk mencapai tingkat perkembangan optimal, tetapi hasil penelitian menyatakan bahwa hanya 5\% potensi otak yang terpakai karena kurangnya stimulasi yang berfungsi untuk mengoptimalkan fungsi otak[6].

Menurut beberapa ahli keperawatan diantaranya Paplau H mengatakan bahwa kesehatan adalah proses yang berlangsung mengarah kepda kretifitas, konstruktif, dan produktif. Dengan demikian bahwa kesehatan adalah suatu hal yang tidak dapat dianggap sepele keberadaannya dalam membentuk sumber daya manusia yang unggul. Bidang kesehatan perlu mendapatkan perlakuan dan perhatian khusus guna menunjang kepentingan pembangunan karakter bangsa[7]. Gizi meningkatkan pertumbuhan dan perkembangan, kesehatan serta kesejahteraan anak-anak di masa yang akan datang. Orang tua, guru pendidikan anak usia dini, dan pengelola PAUD bagi menentukan anakanak mengamalkan gizi yang sehat dan seimbang serta sikap yang positif dari gaya hidup sehat. Data Riset Kesehatan Dasar (Riskesdas) 2010 tentang prevalensi status gizi balita untuk Provinsi Sulawesi Utara diperoleh diperoleh gizi buruk 4,3\%, gizi kurang 11,5\%, gizi baik 80,7\%, dan gizi lebih 3,6\%.3 .Untuk prevelensi status gizi nasional, prevalensi berat kurang pada tahun 2013 yaitu 19,6\% dimana 5,7\% gizi buruk dan 13,9\% gizi kurang. Data di Sulawesi Utara untuk 2013 menunjukkan prevalensi status gizi BB/TB<-2SD tahun 2013 adalah 10\% [8]. Kabupaten Bolaang Mongondow Timur berdasarkan data jumlah penderita gizi buruk setiap tahun mengalami penurunan. Sejak 2017 jumlah penderita kasus gizi buruk di Boltim berjumlah dua orang. Pada 2018 tiga orang, sedangkan 2019 turun jadi satu orang. Biasanya penyakit ini menyerang anakanak berumur 0-59 bulan. Ada upaya perhatian pemerintah terkait dengan penanganan gizi buruk hingga angka peningkatan gizi balita[9].

Pola makan yang terbentuk sangat erat kaitannya dengan kebiasaan makan seseorang. Secara umum faktor yang mempengaruhi terbentuknya pola makan adalah faktor ekonomi, sosial budaya, agama, pendidikan, dan lingkungan[10]. Saat pandemi Covid-19 di Kabupaten Bolaang Mongondow Timur tingkat ekonomi masyarakat terjadi penurunan sehingga dapat mempengaruhi peluang untuk membeli pangan dengan kuantitas dan kulitas yang lebih baik. Hal ini akan mempengaruhi asupan gizi bagi anak. Ketika masyarakat mengalami masalah ekonomi karena kehilangan pendapatan dan memiliki akses yang terbatas ke makanan sehat, jumlah anak yang kekurangan gizi akan cenderung meningkat di tengah angka yang memang sudah tinggi. Hal ini sangat mengkhawatirkan karena asupan makanan bergizi sangat penting untuk meningkatkan kekebalan tubuh guna mencegah dan melawan COVID-19 khusunya pada anak usia dini . Anak usia sekolah dengan kondisi ekonomi keluarga baik yang bersekolah di pusat kota memungkinkan anak memiliki status kesehatan yang lebih baik dibandingkan dengan anak yang bersekolah dan tinggal di pinggiran kota. Pusat kota merupakan tempat yang memiliki pusat pelayanan yang tinggi untuk memenuhi kebutuhan, seperti: fasilitas pertokoan, perbelanjaan, fasilitas untuk mengakses informasi dan kesehatan. Sedangkan, anak yang bersekolah dan tinggal di daerah pinggiran kota dengan segala fasilitas yang tersedia dan kondisi sosial ekonomi keluarga yang terbatas 
memungkinkan anak mempunyai status kesehatan dan gizi yang buruk dibandingkan dengan anak yang tinggal di pusat kota[11].

Status gizi adalah keadaan tubuh sebagai akibat konsumsi makanan dan penggunaan zat-zat gizi. Dibedakan antara status gizi buruk, kurang, baik, dan lebih. Secara klasik kata gizi hanya dihubungkan dengan kesehatan tubuh, yaitu untuk menyediakan energi, membangundan memelihara jaringan tubuh serta mengatur proses-proses kehidupan dalam tubuh. Tetapi, sekarang kata gizi mempunyai pengertian lebih luas, disamping untuk kesehatan, gizi dikaitkan dengan potensi ekonomi seseorangkarena gizi berkaitan dengan perkembangan otak, kemampuan belajar, dan produktifitas kerja. Penilaian status gizi merupakan penjelasan yang berasal dari data yang diperoleh dengan menggunakan berbagai macam cara untuk menemukan suatu populasi atau individu yang memiliki risiko status gizi kurang maupun gizi lebih.Sedangkan status gizi adalah keadaan keseimbangan dalam bentuk variabel tertentu atau perwujudan dari nutriture (keadaan gizi) dalam bentuk variabel tertentu[12]. Gizi berperan penting dalam pertumbuhan dan perkembangan anak. Di Indonesia, spektrum malnutrisi sangat luas dan terjadi diseluruh tahap kehidupan antara lain dalam bentuk Kurang Energi Protein (KEP), kekurangan zat gizi mikro, berat bayi lahir rendah, dan gangguan pertumbuhan yang dilihat dari indikator tinggi badan menurut umur[13]. Untuk menentukan klasifikasi status gizi digunakan z-score sebagai batas ambang kategori. Standar deviasi unit (z-score) digunakan untuk meneliti dan memantau pertumbuhan serta mengetahui klasifikasi status gizi. Pertumbuhan (growth) berkaitan dengan masalah perubahan dalam besar, jumlah ukuran atau dimensi tingkat sel, organ maupun individu, bersifat kuantitatif sehingga bisa diukur dengan ukuran berat (gram, pound, kilogram), ukuran panjang (cm, meter), umur, tulang dan keseimbangan metabolik (retensi kalsium dan nitrogen tubuh)[14].

Gizi merupakan determinan penting tumbuh kembang anak, tetapi gizi saja tidak cukup, rangsangan juga diperlukan untuk pematangan fungsi tubuh. Pemberian makanan maupun stimulasi yang efektif hanya mungkin diperoleh anak jika ibu atau pengasuh mempunyai pengetahuan, sikap, dan motivasi yang berkenaan dengan pemberian makanan dan stimulasi tersebut. Pendidikan gizi dan stimulasi melalui konseling merupakan kombinasi upaya yang cukup efektif dalam merubah perilaku

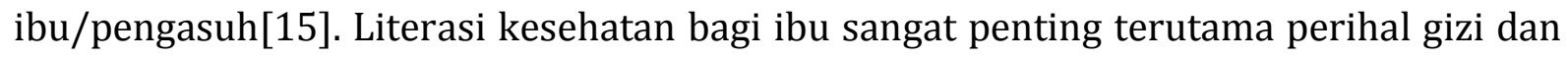
kesehatan anak, mengingat maraknya kasus stunting yang menimpa anak di Indonesia. Penyebab tingginya kasus stunting, khususnya di Bangkalan, Madura adalah pengetahuan ibu yang rendah dalam hal parenting (merawat, mendidik, membimbing). Penelitian ini bertujuan untuk: (1) mengetahui efektivitas kegiatan parenting education guna meningkatkan pengetahuan ibu muda terkait status gizi selama masa kehamilan, dan (2) mengetahui faktor pendukung dan penghambat dalam kegiatan parenting education. Penelitian ini menggunakan pendekatan mixed method (metode campuran) dengan teknik wawancara, dokumentasi, observasi, dan tes yang hasilnya akan dianalisis secara kualitatif dan kuantitatif. Hasil analisis data menunjukkan kegiatan parenting education untuk pencegahan stunting dinyatakan efektif berdasarkan 
perhitungan uji-t sehingga terdapat perbedaan signifikan antara pengetahuan ibu muda sebelum dan sesudah mengikuti parenting education[16].

Kelompok anak usia sekolah merupakan salah satu kelompok rentan gizi. Meskipun kelompok umur ini mempunyai kesehatan yang lebih baik dibandingkan kesehatan anak balita, tetapi kelompok ini dapat timbul masalah-masalah kesehatan, seperti: berat badan rendah, defisiensi zat besi, dan defisiensi vitamin E. Pendidikan taman kanak-kanak (TK) Ekasari Buyat I adalah merupakan salah satu bentuk PAUD (Pendidikan anak Usia Dini) yang berada di Desa Buyat I Kabupaten bolaang mongodow timur yang bertujuan mengembangkan kepribadian anak dan mempersiapkan kejenjang sekolah dasar.selain itu juga untuk membentuk anak yang berkualitas, yaitu anak yang tumbuh dan berkembang sesuai dengan tingkat perkembangannya sehingga memiliki kesiapan yang optimal di dalam memasuki pendidikan dasar serta mengarungi kehidupan di masa dewasa. Berdasarkan latar belakang peneliti melakukan penelitian Deskripsi status gizi anak usia 3 sampai 5 tahun pada masa covid di PAUD/TK Ekasari Buyat I Kabupaten Bolaang Mongondow Timur.

\section{METODE}

Metode penelitian yang digunakan adalah metode survey termaksud dalam penelitian Deskriptif dengan menggunakan metode cross-sectional yaitu penelitian yang pengukuran variabel - variabelnya dilakukan hanya satu kali pada satu saat.Penelitian ini di laksanakan di PAUD/TK Ekasari Buyat I. Waktu penelitian bulan Februari Sampai Mei 2020. Populasi dan sampel dalam penelitian ini berjumlah 27 orang. Variabel anak Paud/Tk Ekasari buyat I umur 3-5 tahun, berat badan, tinggi badan dan status Gizi. Data yang didapat oleh peneliti berdasarkan hasil penelitian berupa karakteristik anak, serta status gizi balita diperoleh dengan wawancara serta langsung menggunakan alat bantu timbangan berat badan dan Pengukuran tinggi badan menggunakan stadiometer untuk anak umur 3 - 5 tahun dan data umum mengenai karakteristik responden diperoleh melalui wawancara dengan menggunakan kuisioner.Lalu data diolah dengan menggunakan sistem tabulasi dan analisa dengan persentase. Pengumpulan data pada penelitian ini berdasarkan data primer yang didapatkan dari pengisian lembar isian responden untuk mengetahui umur siswa dan pemeriksaan fisik yaitu mengukur berat badan dan tinggi badan untuk menentukan indeks massa tubuh. Kemudian mengkategorikan hasil status gizi berdasarkan nilai z-score yang diperoleh dari tabel Kepmenkes 2010 tentang Standar Antropometri Penilaian Status Gizi Anak. Setelah pengumpulan data selesai, kemudian dilakukan pengolahan data yaitu data yang didapat dari lembar isian responden dan pengukuran IMT kemudian dihitung sesuai jumlah sampel yang selanjutnya dicatat secara komputerisasi. Data kemudian disajikan dalam bentuk tabel distribusi frekuensi dan penjelasannya. Pengolahan data hasil penelitian dilakukan secara analisis univariat. Pada penelitian ini analisis univariat digunakan untuk melihat gambaran status gizi[17]. ${ }^{9}$ 


\section{HASIL DAN PEMBAHASAN}

Penilaian status gizi pada dasarnya merupakan proses pemeriksaan keadaan gizi seseorang dengan cara mengumpulkan data penting, baik yang bersifat objektif maupun subjektif, untuk kemudian dibandingkan dengan data baku yang telah tersedia dengan tujuan dapat menggambarkan dan menentukan keadaan status gizi seseorang. Indeks Massa Tubuh (IMT) merupakan parameter yang sering digunakan untuk menilai status gizi seseorang. Makanan sehari-hari yang dipilih dengan baik akan memberikan semua zat gizi yang dibutuhkan tubuh untuk berfungsi dengan normal. Sebaliknya bila makanan tidak dipilih dengan baik maka tubuh akan mengalami kekurangan zat. Penilaian status gizisecara langsung dapat dibagi menjadi 4 penilaian,yaitu: Antropometri, Klinis, Biokimia Dan Biofisik. Pengukuran status gizi bertujuan untuk memperoleh suatu gambaran dimana masalah gizi terjadi dan dianalisa faktor-faktor ekologi yang langsung atau tidaklangsung sehingga dapat dilakukan upaya-upaya perbaikan. Pemeriksaan klinis didasarkan atasperubahan-perubahan yangterjadi yangdihubungkan denganketidakcukupan zat gizi.Dapatdilihat pada jaringan epitel (supervicial epithelial tissues) sepertikulit, mata, rambut dan mukosa oral atau pada organ-organ yangdekat dengan permukaan tubuh sepertikelenjar tiroid. Survei ini dirancang untuk mendeteksi secara cepat tanda-tanda klinis umum dari kekurangan salah satu atau lebih zat gizi. Untukmengetahui tingkat status gizi seseorang dengan melakukan pemeriksaan fisik yaitu tanda (sign) dan gejala (symptom) atauriwayat penyakit. Pemeriksaan spesimen yang diuji secara laboratoris yang dilakukanpada berbagai macam jaringan tubuh. Jaringan tubuh yang digunakan antara laindarah, urin, tinja, dan juga beberapa jaringantubuh seperti hati dan otot[1].

Penyakit Covid-19 akan menjadi lebih berisiko ketika anak memiliki penyakit penyerta, seperti pneumonia. Oleh karena itu, penting untuk mempertahankan dan memperbaiki status gizi anak. Kirana mengingatkan karena keterbatasan penghasilan orang tua dapat memberikan efek domino yang menyebabkan penurunan daya beli. Ketersediaan pangan di rumah tangga dan pengetahuan orang tua terhadap pemilihan bahan makanan bergizi dengan harga yang terjangkau menjadi perhatian khusus. Pendemi COVID-19 yang pada perkembangannya menyertakan dampak berupa krisis Air. Ini juga berarti ancaman tambahan bagi kesehatan anak dengan potensi gizi buruk dan stunting dimana-mana. Oleh karena itu, diperlukan kerja sama antarsemua komponen untuk saling bantu, termasuk dalam upaya menjaga pemenuhan gizi anak di masa pandemik. pandemi ini hanya persoalan jangka pendek, namun menjaga tumbuh kembang anak merupakan tugas jangka panjang yang harus terus dilakukan agar persoalan gizi kurang dan gizi buruk tidak bertambah pada anak - anak pada umunya dan khususnya Anak Paud/Tk Ekasari Buyat I. Efek terhadap kekurangan zat gizi akan berpengaruh pada tinggi badan anak dalam kurun waktu yang relatif lama. 
Tabel 1. Distribusi responden berdasarkan jenis kelamin di PAUD/TK Ekasari Buyat I

\begin{tabular}{lll}
\hline Jenis Kelamin Anak & N & \% \\
\hline Laki-Laki & 10 & 37.03 \\
Perempuan & 17 & 62.96 \\
Total & 27 & 100 \\
\hline
\end{tabular}

Dengan melihat tabel di atas dapat di jelaskan bahwa mayoritas murid di PAUD/TK Ekasari Buyat I adalah perempuan dengan jumlah 17 orang (62.96\%) sedangkan jens kelamin laki- laki hanya berkisar 10 orang (37.03\%). Anak laki-laki memiliki kebutuhan gizi yang lebih besar dibanding anak perempuan. Karena anak lakilaki memiliki postur tubuh yang lebih besar dan metabolisme lebih tinggi serta lebih aktif bergerak. Sehingga kebutuhan protein menjadi lebih banyak. Kebutuhan gizi anak perempuan pada masa pertumbuhan rata-rata 2.125 kkal. Sementara anak laki-laki membutuhkan gizi $2.475 \mathrm{kkal}[18]$.

Tabel 2. Distribusi responden berdasarkan usia pada anak usia 3-5 tahun di PAUD/TK Ekasari Buyat I

\begin{tabular}{lll}
\hline Usia Anak & $\mathbf{N}$ & $\mathbf{\%}$ \\
\hline 3 tahun & 2 & 7.4 \\
4 tahun & 5 & 18.5 \\
5 tahun & 20 & 74.1 \\
Total & 27 & 100 \\
\hline
\end{tabular}

Tabel 2 menunjukan bahwa sebagian besar anak berumur 5 tahun 74.1\%Pada masa ini anak memerlukan asupan zat gizi seimbang baik dari segi jumlah, maupun kualitas.Pada usia ini anak 3 - 5 tahun sudah harus makan seperti pola makan keluarga, yaitu: sarapan, makan siang, makan malam dan 2 kali selingan. Porsi makan pada usia ini setengah dari porsi orang dewasa. Memasuki usia 3 tahun pertumbuhan mulai lambat dan permasalahan mulai sulit makan muncul. Sementara itu aktivitas mulai bertambah dengan bermain sehingga makan dapat dilakukan sambil bermain sehingga dapat mempengaruhi pertumbuhan dan perkembangan anak. Semakin bertambah usia anak, maka semakin meningkat pula jumlah kecukupan gizi yang harus dipenuhi setiap harinya[18]. Maka itu sebagai orangtua, Anda dituntut harus selalu memberikan sumber makanan yang bisa membantu memenuhi nutrisi atau gizi anak. Pada rentang usia 3-5 tahun kerap terjad ianak menolak makanan yang tidak disukai dan hanya memilih makanan yang disukai sehingga perlu diperkenalkan kepada mereka beranekaragam makanan[2]. 
Tabel 3.Distribusi responden berdasarkan status Gizi pada anak usia 3-5 tahun di PAUD/TK Ekasari Buyat I

\begin{tabular}{lll}
\hline Status Gizi & n & \% \\
\hline Gemuk & 1 & 3.7 \\
Normal & 22 & 81.5 \\
Kurus & 4 & 14.8 \\
Sangat kurus & 0 & 0 \\
Total & 27 & 100 \\
\hline
\end{tabular}

Setelah melakukan pengukuran status Gizi pada masa pendemi Covid 19 di PAUD/TK Ekasari Buyat I didapatkan hasil yaitu responden dengan status gizi normal sebanyak 22 orang (81.5\%), status gizi gemuk sebanyak 1 orang (3.7\%), status gizi obesitas tidak ada, status gizi kurus sebanyak 4 orang (14.8\%) dan status gizi sangat kurus tidak ada. Dengan melihat hasil di atas dapat di nilai anak usia 3-5 tahun di PAUD/TK Ekasari Buyat I tersebut terdistribusi paling banyak pada status gizi normal. Status gizi normal tersebut memberikan dampak positif bagi proses belajar, karena jika tergolong malnutrisi maka hal tersebut akan menggangu konsentrasi di sekolah maupun di rumah yang berdampak pada prestasi pelajar[19]. Orang tua anak selalu memberikan makan yang baik kepada anaknya pada masa Pandemi Covid 19 karena manyoritas orang tua (ibu) bermata pencaharian sebagai penjual jenis makanan secara online di sekitar Desa. Selain itu juga pemerintah kabupaten bolaaang mongondow timur melalui Desa Buyat I memberikan stimulus bantuan bahan makanan pokok untuk membantu masyarakat dalam memenuhi kecukupan gizi keluarga. Ketidakseimbangan asupan gizi pada anak menjadi dasar timbulnya permasalahan status gizi pada remaja. Bila konsumsi gizi selalu kurang dari kebutuhan maka seseorang dapat mengalami gizi kurang, sebaliknya jika konsumsi melebihi kecukupan maka seseorang akan mengalami gizi lebih[20].

Status gizi merupakan indikator kesehatan yang penting karena anak usia di bawah lima tahun merupakan kelompok yang rentan terhadap kesehatan dan gizi. Gangguan gizi pada awal kehidupan akan mempengaruhi kualitas kehidupan berikutnya. Gizi kurang pada balita tidak hanya menimbulkan gangguan pertumbuhan fisik, tetapi juga mempengaruhi kecerdasan dan produktivitas ketika dewasa[21].

Untuk menentukan klasifikasi status gizi digunakan z-score sebagai batas ambang kategori. Standar deviasi unit (z-score) digunakan untuk meneliti dan memantau pertumbuhan serta mengetahui klasifikasi status gizi. Pertumbuhan (growth) berkaitan dengan masalah perubahan dalam besar, jumlah ukuran atau dimensi tingkat sel, organ maupun individu, bersifat kuantitatif sehingga bisa diukur dengan ukuran berat (gram, pound, kilogram), ukuran panjang ( $\mathrm{cm}$, meter), umur, tulang dan keseimbangan metabolik (retensi kalsium dan nitrogen tubuh)[14]. 
Table 4 Pengetahuan orang tua tentang gizi anak pada anak usia 3-5 tahun di PAUD/TK Ekasari Buyat I

\begin{tabular}{lll}
\hline Pengetahuan tentang Gizi & $\mathrm{N}$ & $\%$ \\
\hline Baik & 22 & 81.5 \\
Tidak baik & 5 & 18.5 \\
Total & & 100 \\
\hline
\end{tabular}

Berdasarkan tabel 4 pengetahuan orang tua tentang gizi anak pada usia 3-5 tahun di Paud TK Ekasari Buyat I kategori baik 81.5\% dan tidak baik 18.5\%. Pengetahuan gizi ibu dapat dipegaruhi oleh usia, pendidikan, pengetahuan, pekerjaan dan pendapatan. Selain itu, asupan makan pada anak juga dipengaruhi oleh budaya setempat yang juga dapat mempengaruhi pemilihan makanan oleh ibu. Oleh karena itu, jika seorang ibu memiliki pengetahuan gizi yang kurang maka asupan makanan yang akan diberikan kepada anak juga kurang tepat dan dapat mempengaruhi status gizi anak Menurut Notoatmodjo pengetahuan ibu diklasifikasikan menjadi 2 bagian yaitu kurang $(<75 \%)$ dan baik ( $\geq 75 \%$ ).Tingkat pengetahuan ibu yang tinggi tidak menjamin memiliki balita dengan status gizi yang normal. Ibu yang memiliki pengetahuan yang baik diharapkan mampu mengaplikasikan pengetahuan yang dimiliki dalam kehidupan sehari-hari. Namun, perilaku selain dipengaruhi oleh tingkat pengetahuan juga dipengaruhi oleh faktor lain, misalnya sosio ekonomi, sosio budaya, dan lingkungan[22].

Pengetahuan adalah hasil tahu yang merupakan konsep didalam pikiran seseorang sebagai hasil setelah seseorang tersebut melakukan penginderaan terhadap sesuatu objek tertentu.Pengetahuan seseorang diperoleh dari pengalaman yang pengaruhnya terhadap status gizi balita, hal ini sama dengan penelitian yang meneliti tentang hubungan antara tingkat pengetahuan ibu tentang gizi dengan status gizi balita menyatakan ada hubungan antara tingkat pengetahuan ibu tentang gizi dengan status gizi balita. Hal ini menunjukkanbahwa meskipun pengetahuan bukan merupakan faktor langsung yang mempengaruhi status gizi anak balita, namun pengetahuan gizi ini memiliki peran yang penting. Karena dengan memiliki pengetahuan yang cukup khususnya tentang kesehatan, seseorang dapat mengetahui berbagai macam gangguan kesehatan yang mungkin akan timbul sehingga dapat dicari pemecahannya[23].

Pengetahuan dan peran ibu dalam membina makan sehat sangat dituntut demi mempertahankan pola pemberian makan yang benar pada anak. Makanan selingan anak perlu diperkenalkan sejak anak masuk kemakanan keluarga. Tentunya dipilih yang sesuai dengan usianya yaitu konsistensinya dan porsi. Kesehatan anak merupakan hal yang perlu diupayakan secara serius oleh orang tua. Untuk itu diupayakan pengaturan pola pemberian makan yang tepat seimbang agar anak tetap sehat. Kesehatan anak dapat dicapai melalui upaya pemberian makan yang seimbang sesuai dengan kebutuhan gizinya. Makan seimbang yaitu makan sesuai komposisi bahan makanan yang dibutuhkan tubuh dalam porsi yang disesuaikan dengan kebutuhan anak pada masingmasing usianya. 
Table 5 Distribusi responden berdasarkan usia orang tua pada anak usia 3-5 tahun di PAUD/TK Ekasari Buyat I

\begin{tabular}{lll}
\hline Usia Orang Tua & $\mathbf{n}$ & $\mathbf{\%}$ \\
\hline $\mathbf{2 1}$ & 2 & 7.4 \\
$\mathbf{2 2}$ & 1 & 3.7 \\
$\mathbf{2 3}$ & 2 & 7.4 \\
$\mathbf{2 4}$ & 2 & 7.4 \\
$\mathbf{2 5}$ & 3 & 11.1 \\
$\mathbf{2 6}$ & 2 & 7.4 \\
$\mathbf{2 7}$ & 3 & 11.1 \\
$\mathbf{2 8}$ & 2 & 7.4 \\
$\mathbf{2 9}$ & 10 & 27 \\
\hline
\end{tabular}

Berdasarkan Tabel 5 bahwa mayoritas usia orang tua pada anak usia 3-5 tahun di PAUD/TK Ekasari Buyat I adalah berumur 29 tahun (27\%). Umur orang tua berpengaruh terhadap pemberian kecukupan gizi anak Paud/Tk saat pendemi Covid 19.Anak usia 2-5 tahun sudah diberikan berbagai macam jenis makanan, termasuk jajanan. Pola makan dan jenis makanan harus benar-benar diperhatikan untuk memastikan kebutuhan nutrisi harian sesuai AKG pada usianya tetap terpenuhi. Pada usia ini pun sering terjadi gangguan pencernaan pada anak, sehingga penting untuk terus mengawasi pola dan jenis makanannya.

Orang tua berperan dalam mengawasi ketika makan tetapi umur orang tua tidak berpengaruh pada pemberian gizi yang akan diberikan pada anaknya.Pola pengasuhan anak berupa sikap dan perilaku ibu atau pengasuh lain dalam hal hakekatnya dengan anak, memberikan makan, merawat, kebersihan, memberi kasih sayang dan sebagainya. Kesemuanya berhubungan dengan keadaan ibu dalam hal kesehatan (fisik dan mental), status gizi, pendidikan umum, pengetahuan dan keterampilan, tentang pengasuhan anak yang baik, peran dalam keluarga atau di masyarakat, sifat pekerjaan sehari-hari, adat kebiasaan keluarga dan masyarakat, dan sebagainya dar si ibu atau pengasuh anak[24]. Menurut Hoerniasih bahwa layanan pengasuhan anak diberikan secara holistik melayani seluruh kebutuhannya untuk tumbuh dan berkembang baik dari kesehatan, gizi, pendidikan, dan perindungan serta secara integratif melakukan kerjasama dengan pihak lembaga pendidikan[25]. Setelah lahir seorang bayi, pasangan suami istri otomatis akan bertambah perannya dengan menjadi orangtua baru. Mereka harus mempersiapkan segala sesuatunya sebagai sebuah keluarga. Mereka harus mendominasi pada proses pengembangan pribadi bagi si anak. Salah satunya dengan membuat kondisi keluarga yang menyenangkan dan menimbulkan rasa nyaman bagi seluruh anggota keluarga, terutama anak. Mengingat hebatnya pengaruh perlakuan orangtua pada anak khususnya pada usia balita, maka segala tindakan kita dalam mengasuh dan membimbing anak harus terkontrol.

Pola pemberian makan pada anak sebagian besar berada dalam kategori baik. Hal ini di latar belakangi oleh tingkat pengetahuan, pendidikan, dan tingkat ekonomi yang baik. Semakin tinggi tingkat pendidikan orang tua maka semakin tinggi pula 
pengetahuan dan pengalamanya dalam merawat anaknya khususnya dalam pola pemberian makannya. Hal, bila ibu rumah tangga memiliki pengetahuan gizi yang baik maka ibu akan mampu untuk memilih makanan-makanan yang bergizi untuk dikonsumsi. Semakin tinggi pengetahuan dan pengalaman ibu dalam merawat anaknya maka akan berpengaruh juga dalam praktik pemberian makanan pada anaknya. Hal ini diperkuat oleh pernyataan, bila ibu memiliki pengetahuan gizi yang baik maka ibu akan mampu untuk memilih makanan-makanan yang bergizi untuk dikonsumsi[23]. Distribusi makanan tambahan dapat terus dilakukan sesuai dengan kebutuhan balita melalui petugas kesehatan dibantu oleh kader sebagai suplementasi untuk mempertahankan kecukupan gizi balita (tetap memperhatikan pembatasan kontak/ physical distancing)[26].

\section{KESIMPULAN (12 PT. CAMBRIA BOLD)}

Deskripsi status Gizi anak gizi anak usia 3 sampai 5 tahun pada masa covid di PAUD/TK Ekasari Buyat I Kabupaten Bolaang Mongondow Timur adalah berada pada batas normal dan Pengetahuan orang tua tentang gizi gizi anak usia 3 sampai 5 tahun pada masa covid di PAUD/TK Ekasari Buyat I Kabupaten Bolaang Mongondow Timur sebagian besar dalam keadaan baik.

\section{REFERENSI}

[1] Almatsier, Prinsip Dasar Ilmu Gizi. Jakarta: PT Gramedia Pustaka Utama, 2009.

[2] Noel WS Manary JM, Aspek kesehatan masyarakat pada gizi kurang gizi kesehatan masyarakat. Jakarta: EGC, 2008.

[3] BPPK Depkes, Riset Kesehatan Dasar. Jakarta: Depkes, 2013.

[4] N. Nurdin and L. O. Anhusadar, "Evaluasi Pelaksanaan Standar Proses di Satuan Pendidikan Anak Usia Dini," J. Obs. J. Pendidik. Anak Usia Dini, vol. 4, no. 2, p. 982, Mar. 2020.

[5] L. Hewi and L. Asnawati, "Strategi Pendidik Anak Usia Dini Era Covid-19 dalam Menumbuhkan Kemampuan Berfikir Logis," J. Obs. J. Pendidik. Anak Usia Dini, vol. 5, no. 1, p. 158, 2020.

[6] Tatik Ariyanti, "Pentingnya Pendidikan Anak Usia Dini Bagi Tumbuh Kembang Anak," J. Din. Pendidik. Dasar, vol. 8, no. 1, pp. 50-58, 2016.

[7] Sumiman Udu;La Ode Anhusadar;Alias;La Ali, "Hedole-dole: Metode Tradisional Masyarakat Wakatobi Mencegah Stunting," Al-Izzah J. Hasil-Hasil Penelit., vol. 14, no. 2, pp. 32-41, 2019.

[8] Departemen Kesehatan, Riset kesehatan dasar 2013. Jakarta: Badan Litbangkes Depkes RI, 2013.

[9] Dinas Kesehatan Bolaang Mongondow Timur, Profil kesehatan tahun 2019: Dinas Kesehatan Boltim. Bolaang Mongondow Timur: Dinas Kesehatan Boltim, 2019.

[10] Geiby Waladow;Sarah M. Warouw;Julia V. Rottie, "Hubungan pola makan dengan status gizi pada anak usia 3-5 tahun di wilayah kerja Puskesmas Tompaso," J. Keperawatan, vol. 1, no. 1, pp. 1-6, 2013.

[11] Roedjito, Kajian penelitian gizi, Edisi ke-1. Jakarta, 1989.

[12] Arisman, Gizi dalam Daur Kehidupan Gizi Anak. Jakarta: EGC, 2007.

[13] Rindu Dwi Malateki Solihin, "Kaitan Antara Status Gizi, Perkembangan Kognitif, 
Dan Perkembangan Motorik Pada Anak Usia Prasekolah," Penelit. Gizi dan Makanan, vol. 36, no. 1, pp. 62-72, 2013.

[14] E. Purwani and Mariyam, "Pola Pemberian Makan Dengan Status Gizi Anak Usia 1 Sampai 5 Tahun Di Kabunan Taman Pemalang," J. Keperawatan Anak, vol. 1, no. 1, pp. 30-36, 2013.

[15] D. Darwati, M. Mexitalia, S. Hadiyanto, F. Hartanto, and S. A. Nugraheni, "Pengaruh Intervensi Konseling Feeding Rules dan Stimulasi Terhadap Status Gizi dan Perkembangan Anak di Posyandu Kabupaten Jayapura," Sari Pediatr., vol. 15, no. 6, pp. 377-384, 2014.

[16] S. F. Fitroh and E. Oktavianingsih, "Peran Parenting dalam Meningkatkan Literasi Kesehatan Ibu terhadap Stunting di Bangkalan Madura," J. Obs. J. Pendidik. Anak Usia Dini, vol. 4, no. 2, pp. 610-619, 2020.

[17] Sugiyono, Metode Penelitian Kuantitatif, Kualitatif dan R\&D. Bandung: Alfabeta, 2007.

[18] M. . Gibney, Gizi Kesehatan Masyarakat. Jakarta: EGC, 2009.

[19] Soekidjo Notoatmodjo, Pendidikan Dan Perilaku Kesehatan. Jakarta: Rineka Cipta, 2003.

[20] Sulistyoningsih H, Gizi untuk kesehatan ibu dan anak. Jogjakarta: Graha Ilmu, 2011.

[21] A. Aswar, Gizi Seimbang Menuju Hidup Sehat bagi Balita. Jakarta: Departemen Kesehatan Dan Kesejahteraan RI, 2002.

[22] L. Handayani, S. A. Mulasari, N. Nurdianis, F. K. Masyarakat, and U. A. Dahlan, "Evaluasi Program Pemberian Makanan Tambahan Anak Balita Evaluation of Supplement Feeding ' S Programme To Children Under Five Years Old," J. Manaj. Pelayanan Kesehat., vol. 11, no. 01, pp. 21-26, 2008.

[23] Soekidjo Notoatmodjo, Ilmu Kesehatan Masyarakat. Jakarta: Rineka Cipta, 2005.

[24] S Santoso;Anne Lies, Kesehatan dan gizi. Jakarta: Rineka Cipta, 2009.

[25] S. Setianingrum, L. Desmawati, and A. Yusuf, "Peranan Kader Bina Keluarga Balita dalam Optimalisasi Tumbuh Kembang Fisik Motorik Anak Usia Dini," J. Nonform. Educ. Community Empower., vol. 1, no. 2, pp. 137-145, 2017.

[26] Kemenkes, Panduan pelayanan kesehatan balita pada masa tanggap darurat COVID-19. Kemenkes, 2020. 